\title{
Hipodromy jako wielofunkcyjne, sportowo-rekreacyjne przestrzenie zielone w strukturze wspótczesnych miast
}

\author{
Hippodromes as multifunctional, sports and \\ leisure green spaces in the structure \\ of contemporary citie
}

Streszczenie

Hipodrom jest jedną z najstarszych form obiektu sportowego, przeznaczoną do organizacji pokazów i wyścigów konnych. Tradycja budowy tego typu struktur sięga czasow Starozytnej Grecji i Cesarstwa Rzymskiego. Obecnie są to rozległe założenia, zajmujajce powierzchnię nawet kilkudziesięciu hektarow, polożone nierzadko w strefach centralnych dużych miast wanie rozwoju hipodromów wraz z towarzyszacymi im obiektami i urzadzeniami, jako tzw. parków jeździeckich", taczacych elementy sportowe i rekreacyjne, przy zachowaniu podstawowej funkcji, jaką sa wyścigi konne, pozwala na ich przeksztatcenie w wielofunkcyine, miejkie przestrzenie zielone o dużej wartości społecznej i krajobrazowej. Dzieki temu nabieraja on znaczenia nie tylko w skali miast, ale także całych regionów i cieszą się stale rosnąca popularnością jako miejsca spędzania czasu wolnego. W artykule zaprezentowane i przeanalizowane zostaną wybrane przykłady hipodromów z Polski i Europy, pod kątem ich znaczenia dla zrównoważonego rozwoju miast.

\section{Abstract}

Hippodrome is one of the oldest forms of a sports facility, intended for organizing horse shows and races. The tradition of constructing such objects dates back to the times of Ancient Greece and the Roman Empire. Today, these are extensive facilities, occupying area of even several dozen of hectares, often located in the central zones of big cities. They are used not only for shows and competitions, but also for everyday horse riding and EAT (Equestrian Assisted Therapy). Modern development of hippodromes with accompanying buildings and infrastructure as so-called "equestrian parks", combining sports and recreational elements, while maintaining the basic function of horse racing, allows them to be transformed into multifunctional, green spaces of high social and landscape values. As a result, they take on significance not only in the cities, but entire regins and noys icrasing populity as places overday examples of hippodromes from Poland and Europe, in terms of their impotan in

Słowa kluczowe: hipodrom, tor wyścigów konnych, miejskie przestrze
Key words: hippodrome, racecourse, sports and leisure urban spaces

1. Hipodromy - definicja i historia powstania ${ }^{1}$

Hipodrom jest uważany za jedną z najstarszych form obiektu sportowego, przeznaczoną do organizacji pokazów i wyścigów konnych. Jego nazwa wywodzi się z greckiego słowa

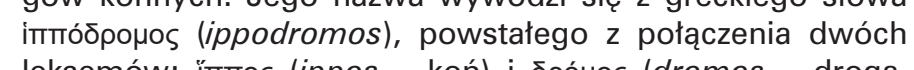

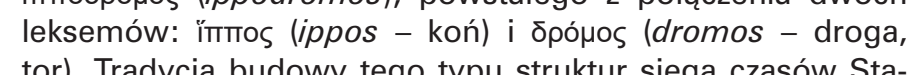
tor). Tradycja budowy tego typu struktur sięga czasów Starożytnej Grecji, być może nawet okresu pierwszych igrzysk
olimpijskich, do których konkurencje hippiczne wprowadzo-
1. Hippodrome - definition and history of creation 1 Hippodrome is considered one of the oldest form of a sports facility, intended for the organization of horse shows and competitions. Its name is derived sulted from the combination of two lexomos: , re(ippos - horse) and סоónos (dromos - road, track). The tradition of such structures dates back to the times of Ancient Greece, perhaps even the period no około 680 r. p.n.e. Klasyczny grecki hipodrom posiadał ksztalt wydłuz p. koncu i wymiarach: szerokosci od ok. 37-120 m. i dugości ok. 180-228 m. Obiekt był przewaznie lokalizowany w zboczu wzgórza, co pozwalato na wykorzystanie naturalnego spadku terenu do uksztaltowania schodkowej widowni po jedne stronie, podczas gdy do budowy wznoszących się siedzisk wzdłuż drugiego boku używano pozyskanej z wykopów ziemi. Trybuny claggnęly się rownieź wzdluz zaokraglonej częśs trybura. Wrack dla prominentów i muzków. Wzdtuż drugiego krótkiego boku toru znajowat sie tzw. portyk Agnaptosa (od imienia jego architektal a za nim uformowane w ksztatt litery V miejsca startowe dla rydwanów i jeźdźców oraz znak startowy w formie ołtarzy: Zeusa (rzeźba orła) oraz Neptuna (rzeźba delfina), Zasadnicza cześć założenia stanowił tor wyścigowy, który składał sie $z$ dwóch długich prostych oraz dwóch ciasnych zakretów o 180 stopni, na których ustawione były specjalne znaki celowe - zwrotnice tzw. termai, które trzeba było ominąc. Srodkiem toru ciągnął się wał ziemny lub niska sciana zdobiona rzezbami tzw. spina, na ktorej lewym koncu ustawiano "ottarz strachu" o czerwonej barwie tzw. tyraxipia mający utrudniać bieg koniom [il. 1].

Starożytnej Helladzie wyścigi rydwanów i jazda konna były tak popularne, ze hipodromy wznoszono niemal w każdym większym mieście². Najbardziej znane założenia znajdowały się W miejscach, w ktorych odbywaly się igrzyska sportowe czy m.in. w Olimpil, Lykajos, a także Delfach, Nemei czy na wyspie

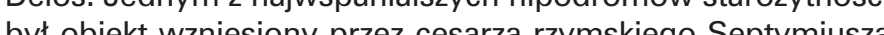
Sera w roku 203 n e w Konzanty but), który mógt goścí 60000 widzów. Już wówczas był to obiekt wielofunkcyjny - organizowano na nim nie tylko zawody disciplines were introduced around $680 \mathrm{BC}$. The classic Greek hippodrome had the shape of an clongated rectangle with one side rounded and $d$ $m$ of length. The object was often locted in the hillside, which allowed the use of a natural slope to construct step-shaped tribunes on one side, while the excavated earth was used to build the rising seats along the second side. The stands also conIn the finishing line there were seats for judges, as well as special honorary tribune for prominent and musicians was placed on the stands. Alon the second short side of the track was located socalled portico of Agnaptos (from the name of it architect), followed by V-shaped starting areas for of altars for Zeus (represented by eagle) and Neptune (represented by dolphin). The main part of the hippodrome was a racetrack, which consisted of two long straights and two tight turns by 180 degrees, on which spectal purpose signs - termai embankment or a low wall decorated with a solptures called spina. At its left end was located so called "altar of fear" - tyraxipia, coloured red to fear horses during race [il. 1 .

Ancient Hellas chariot races and horse riding were so popular, that hippodromes were built in eses were located in the places where the sports games were held, i.e. in Olympia, Lykajos, as well as Delphi, Nemei or on the island of Delos. One of the most magnificent hippodromes of antiquity was the object erected by the Roman Emperor ent Istanbull), which could host 60000 spectators. Already at that time it was a multi-purpose facility -

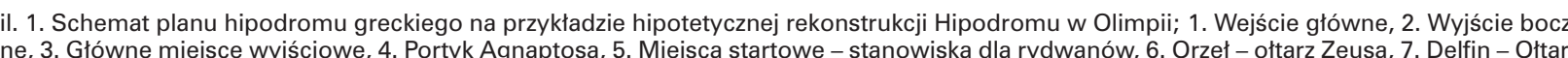

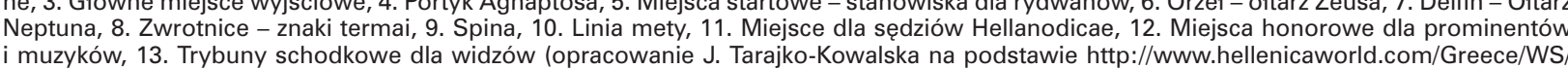

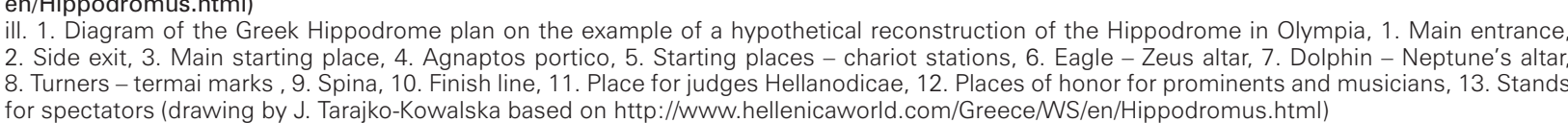

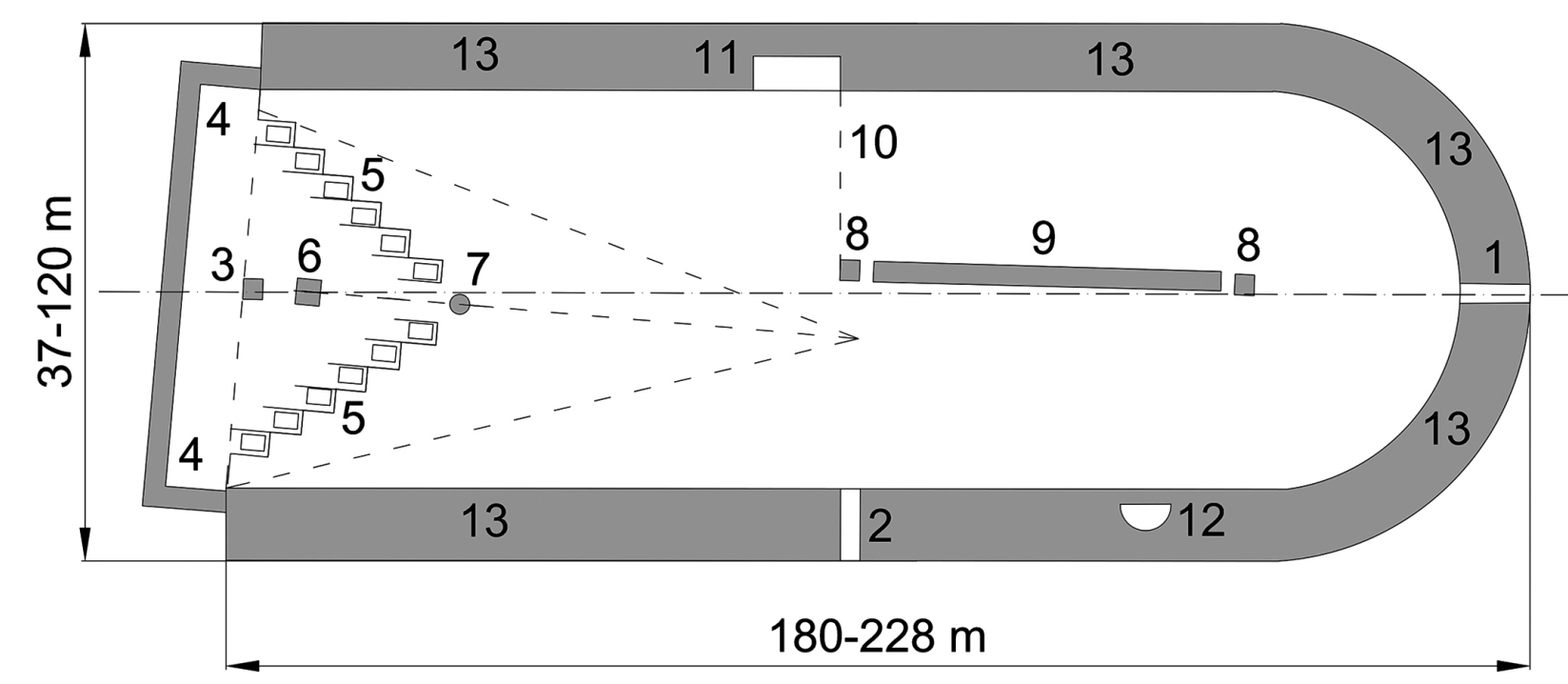


konne, ale także różnego rodzaju ceremonie, parady wojskowe, polityczne demonstracje a nawet publiczne egzekucje.

W okresie Cesarstwa Rzymskiego, a potem takze we wczesnych wiekach Cesarstwa Bizantyjskiego, funkcje hipodromu przejęły cyrki, ktorych plan w porownaniu do greckiego pierwowzon zostal znacznie zwężony i wydlużony. Największym tego typu obiektem był czterokondygnacyjny Circus Maximus W Rzymie, który mógl pomiescic ponad 100000 osob. Choć cyrki rzymskie stały się póńniej protoplastami budynków ne hipodromy greckie na wiele stuleci popadły wapomienie. Wokresie Średniowiecz, a nawet Renesansu zainteresowanie obiektami sportowymi nie było zbyt duzie i te odziedziczone po starożytności zostały w wiekszości zniszczone lub przebudowane. Wyścigi konne, których popularność nigdy nie ostabła, organizowano najcześciej na miejskich placach albo poza miastem, wznosząc jedynie tymczasowe zadaszenia i trybuny dla ważniejszych osobistości. Odrodzenie budynków stadionowych a wraz z nimi także hipodromów, przypada na duża skalę dopiero po rewolucji przemysłowej $\mathrm{i}$ wiaże się $\mathrm{m}$.in. z przywróceniem organizacji igrzysk olimpijskich, których pierwsza nowożytna edycja odbyla się $W 1896 \mathrm{r}$. W Atenach [John et.al. 2013]. Dlatego też dopiero XIX w. uważany jest za początek współczesnych hipodromów europejskich, choć nie brak obiektơw znacznie wczesniejszych, szczegölnie w krajach, w których zawsze kultywowano tradycje sportów konnych, jak Wielka Brytania czy Francja ${ }^{3}$. Za najstarszy, funkcjonujący do dzis tor wyścigowy uważany jest brytyjski Chester Racecourse, znany jako Roodee, który zostal otwarty w roku 1540 w Chester. Przez niemal 300 lat byl to jednak tylko duzy owalny plac nim dopiero w 1817 r. [Roberts 2013]

2. Współczesne hipodromy $i$ ich funkcje $w$ strukturze miast

Wurpółczesne hipodromy zasadniczo różnią sie od swoich historycznych pierwowzorów, choć podobnie jak w Starożytnej Grecji sa to założenia o charakterze krajobrazowym. Dzisiaj to rozległe tereny, zajmujace powierzchnie nawet kilkudziesięciu hektarów, położone w strefach obrzeżnych, a czasem nawet centralnych dużych miast, wykorzystywane nie tylko do pokazów i zawodów, ale także do codziennej rekreacji konnej i hipoterapii. Planowanie hipodromów jako tzW. „parkow jezdzleckich" sprawia, że stają się one równiez wartosciowymi miejskimi terenami zielonymi i miejscami wypoczynku dla całych rodzin [il.2].

Najważniejszą częścią hipodromu jest główny tor wyścigowy do wyścigów płaskich (Flat racing) o długości 1600-2400 m. i szerokosci kilkunastu metrow, co przy elipsoidalnym planie daje wymiary osi dlugiej 700-1000 m i krotkiej 300-500 m. ni: travioj (turfh piaskowe (dirt) lub nach podtozu syntetycznym (all-weather)4. Obok toru glównego sytuowana jest takí bieżnia robocza o nawierzchni piaskowej, przeznaczona do ujeżdzania i ćwiczeń. Na wewnetrznym owalnym placu trawiastym, wyznaczonym przez bieżnie zewnetrzna organizowane sa wyścigi przeszkodowe (Jump Racing). Lokalizuje się tam również dodatkowe place o nawierzchni piatrybun padok (paddock) czyli plac pokazowy do prezentacji koni przed gonitwami oraz rozprężalnię. Do najważniejszych obiektów związanych z wyścigami należą: trybuny dla wi- not only horse competitions were organized there but also various ceremonies, military parades, poDuring tho hrations and even public execulions. Iy centuries of the Byzantine Empire, the functions of the hippodrome were taken over by circuses, whose plan in comparison to the Greek one was significantly narrowed and lengthened. The larges facility of that type was the four-storey Circus Maxi000 people. Although Roman circuses over 100 came the ancestors of modern stadium buildings, they - together with classical Greek hippodromes - fell into oblivion for many centuries.

During the Middle Ages and even Renaissance, the interest in sports buildings was not too great an stroyed or rebuilt. Horse races, which populaity has never been weakened, were usually organized on town squares or outside the cities, where only temporary canopies and stands for major personalities were built. The rebirth of stadium buildings, as well as hippodromes, took place on a large scale among others, with the reinstatement of the Olympic Games, whose first modern edition was held in 1896 in Athens [John et.al. 2013]. Therefore, it is only the 19th century, that is considered the beginning there are also earlier hippodromes era, althoug where traditions of equestrian sports have always been cultivated, such as Great Britain or France ${ }^{3}$. The British Chester Racecourse, known as Roodee, which was opened in 1540 in Chester, is considered to be the oldest racing track still functioning today.
For nearly 300 years, however, it was just a large oval grassy area, and the first grandstand for the public was built there only in 1817 [Roberts 2013].

\section{Modern hippodromes and their functions in the} Coropean cities

Cir hisory hippodromes are very different from Greece they are landscape premises. Today, these are extensive areas, covering up to several dozen of hectares, located usually in peripheral zones of the cities, used not only for shows and competitions but also for everyday horse riding and EAT (Equesso-called "equestrian parks" makes them also valuable urban green areas and places of everyday leisure for entire families [il.2]

The most important part of the hippodrome is the main race track for Flat Racing with a length of
$1600-2400 \mathrm{~m}$ and a width of over a dozen of ters, which, according to the ellipsoid plan of the course, gives dimensions of a long axis 700-1000 m and a short one $300-500 \mathrm{~m}$. The races can be organized on three different types of surface: grass (turf), sand (dirt) or on synthetic ground (all-weather). race track for exercises. The Jump Racing is a dift nized on the inner, oval, grassy square designated by the line of the external main course. Additiona squares with a sand surface are also located there, such as a dressage or educational one and, in fron of grandstands, paddock - special site for horses
presentation before race. The most important objects associated with races include: grandstands for spectators, totalizator with cash registers, jockeys

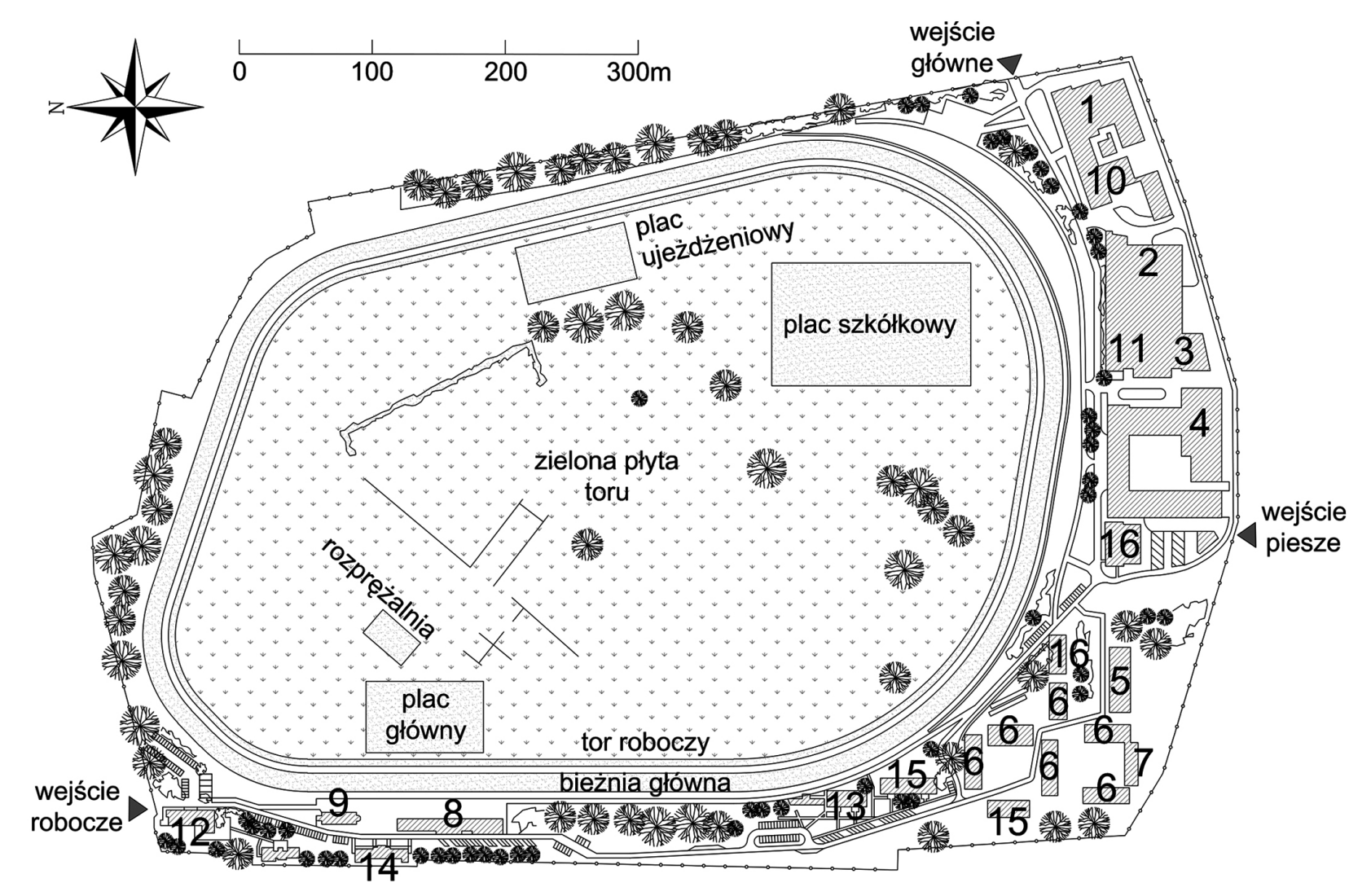

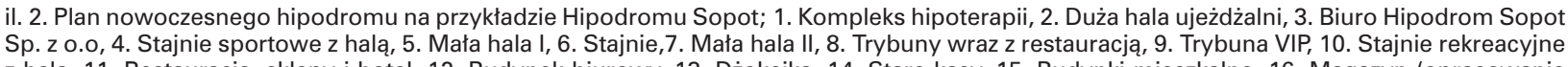
2 hala, 11. Restauracja, sklepy i hotel, 12. Budynek biurowy, 13. Díokejka, 14. Stare kasy, 15. Budynki mieszkalne, 16. Magazyn (opracowanie

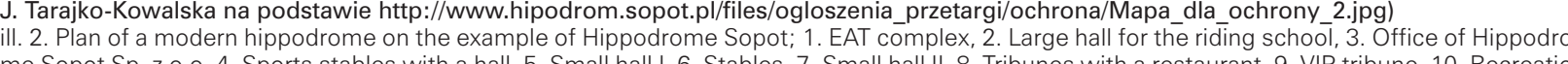

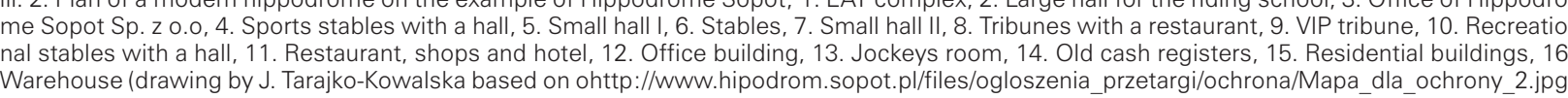

dzów, totalizator z kasami, dżokejka (tzw. waga), stajnie oraz . się równiez gabinety weterynary ne z salami zabiegowy oraz boksami dla chorych koni, a przy większych ośrodkach

$W$ ostatnich latach wiele hipodromów, użytkowanych często nieprzerwanie od XIX wieku przechodzi istotne modernizacje rozbudowy, w wyniku których uzyskują współczesną form przestrzenna i moga sprostac wyzwaniom XXI wieku. Jedna

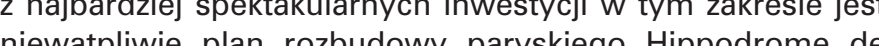
Longchamp - toru działającego od 1857 r który jest nie tylko miejscem organizacii prestiżowych zawodów Oatar Prix de l'Arc de Triomphe, ale także aktywnym centrum sportu i rekreacii To 57 hektarowe zatozienie zlokalizowane jest w Lasku Bulońskim (Bois de Boulogne) nad brzegiem Sekwany. Wyznaczonych jest tu aż 46 różnych punktów startowych oraz (uz stopniem trudności. Obiekt może pomieścić 50000 widzów 5 . W roku 2015 rozpoczęto całkowitą renowację założenia, która ma sprawić, że Hipodrom Longchamp nie tylko utrzyma status jednego z najważniejszych na świecie obiektów wyścigo- room (so-called weight), stables and service building: wachouse, workshop, technical, office and

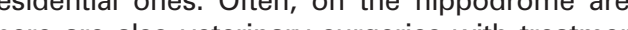
rooms and boxes for sick horses, and at larger cenrofessional horse clinics.

In recent years, many hippodromes, which have 政 to spatial form to meet the challenges of the 21 st in this area is undoubtedly the expansion plan of the Paris Hippodrome de Longchamp - a track op列 Prix de l'Arc de Triomphe, but also an active Canter Pris de 57 hectare site is $10-$ cated in the Bois de Boulogne (Bois de Boulogne) On the banks of the Seine. There are as many as 46 d ferent starting points and several tracks differing The facility can accommodate over 50000 spectetors ${ }^{5}$. In 2015, a complete renovation was started not only maintain the status of one of the world's
not 
wych, ale stanie się również jednym z największych terenów zielonych stolicy Francji. Projekt, ktorego wykonanie powie $\mathrm{mu}$ architektowi Dominique Perrault, uwzględnia założenia przyjętego w 2011 r. planu rewitalizacji całego miasta, w tym zwiększenie powierzchni terenów zieleni miejskiej. Uroczyste otwarcie planowane jest na koniec kwietnia 2018 roku'.

Jednym $z$ istotnych elementów modernizacji podejmowanych na terenach hipodromów są trybuny dla widzów, któtoniczna wizytówke? Wajo wspomnieć tutaj hiszpáski tor Zarzuela w Madrycie (Hipódromo de la Zarzuela) zaprojektowany w 1934 roku przez architektów Carlosa, zaprojeki Martína Domíngueza oraz konstruktora Eduardo Torroja uważanego za czołowego reprezentanta strukturalizmu ekspresyjnego w Europie. Zaprojektowane przez niego trybuny to przykład pionierskiej, betonowej konstrukcji łupinowej, której renowacji podjeło sie w 2004 r. biuro Junquera Architects, dzięki czemu zabytkowa struktura została przywrócona do dawnej swietnosci, a zamknięty w 1997 r. tor ponownie otwarty ${ }^{8}$ W tym samym roku renowacji poddano również zabytkową zeliwną trybunę, wzniesioną na słynnym niemieckim torze Cologne-Weidenpesch (Kolner Renn-Verein 1897 e.V.) w 1898 roku przez Otto Marcha - berlińskiego architekta autora wielu obiektow stadionowych. Jednak na wielu torach dotychczasowe trybuny nie posiadaja juz wystarczającej pojemności i konieczna jest budowa nowych. Ze względu na prestizowy charakter inwestycji nie dziwi fakt, że ich projekty stają się coraz częściej przedmiotem międzynarodowych konkursow archick canicznych. Jako przyklad może posłużyć królowa Anne w 1711 r. gdzie rokrocznie w trakez bytyjska Royal Ascot bywa takz królowa Elżbieta II oraz inni cztonkowie brytyjskiej rodziny królewskiej10. W 2006 roku oddano tu do użytku monumentalna, nowoczesna trybune o długości $480 \mathrm{~m}$. przeznaczoną dla 30000 widzów, zaprojektowana przez architektów z międzynarodowej grupy Populous ${ }^{11}$.

Nowoczesne hipodromy rozszerzaja również swoja działalność o dodatkowe funkcje rekreacyjne, które gwarantuja moż liwość użytkowania tych obiektów przez cały rok, a nie tylko w czasie imprez wyscigowych, jak to miało miejsce dawniej. Odbywają się tu już nie tylko zawody konne i zaprzęgów kłusakow, ale także rożne imprezy artystyczne np. koncerty rockowe, wystawy plenerowe, imprezy integracyjne i sportowe z przerożnych dyscyplin, zloty, targi, pokazy i wiele innych. Poszerza się rowniez program funkejonalny hipodromów m.in. o stajnie rekreacyjne, kryte hale ujeżdżalni z towarzyszacym im zapleczem socjalno-klubowym, centra hipoterapii, sale konferencyje i hotele, dodatkowe place piaszczyste a nawet place zabaw i trasy space
leni [Tarajko-Kowalska et.al.2017].

\section{Hipodromy w Polsce}

whują obecnie cztery hipodromy: Tor wyścigów konnych Służewiec w Warszawie, Wrocławski Tor Wyścigów Konnych we Wrocławiu, Hipodrom Sopot w Sopocie, a od 2012 r. także Krakowski Tor Wyścigów Konnych w Buczkowie-Dąbrówce (k. Bochni) $)^{12}$. Pomimo iż w porównaniu do innych państw europejskich obiekty te sa nieliczne, to jednak są to założenia na najwyższym światowym poziomie, a mo-
dernizacje prowadzone obecnie na ich obszarach moga służyć jako modelowe przykłady i kierunki przekształcen. most important race facilities, but will also become one of the largest green areas in the French capita. by an internation implementation was entrusted by an international competition to the French ar-
chitect Dominique Perrault, takes into account the assumptions of the revitalization plan for the entire city adopted in 2011, including the increase of the urban green areas. The official opening of the new hippodrome is planned for the end of April $2018^{6}$. undertaken in the hippodroments of modernization stands for spectators, which historic construction are often emblematic? It is worth mentioning here the Spanish racecourse Zarzuela in Madrid (Hipodromo de la Zarzuela), designed in 1934 by architects Carlos Arniches and Martín Domínguez an representative of expressive structuralism in rope. The stands designed by him are an example
of a pioneer, concrete shell structure, declared a Historic Artistic Monument in 1980. Thanks to its successful renovation in 2004, carried by the Junquera
Architects, this distinctive structure was restored to its former glory, and the track - closed in 1997 - was re-opened again'. In the same year, on the famous German track Cologne - Weidenpesch (Kolner Ren - Verein 1897 e.V.), the historic cast-iron stand was renovated, erected in 1898 by Otto March - a Berliner architect, author of many stadium buildings. longer have sufficient capacity and it is necessary to build the new ones. Due to the prestigious character of the investment, it is not surprising that their projects are oftentimes the subject of internationa architectural competitions. An example is the mos famous British Ascot Racecourse, founded by the II and other members of the British royal family are present during the Royal Ascot competition every year ${ }^{10}$, where in 2006 a monumental, modern grand struction, designed by architects from the internatiodern hulous group for 30000 spectators

with additional recreational functions, that guaran tee the possibility of using these facilities not only during racing events, but throughout the year. No there, but also various artistic events, there, but also various artistic events, such as:
rock concerts, outdoor exhibitions, integration and sports events from various disciplines, fairs, shows and many more. The functional program of hippodromes develops as well, including: recreationa stables, indoor riding halls with accompanying
social and club facilities, EAT centers, conference social and club facilities, EAT centers, conference
rooms and hotels and even playgrounds and walking routes traced among greenery [Tarajko-Kowalska et.al.2017].

3. Hippodromes in Poland

In Poland, there are currently operating four hippoRacecourse in Partynice, Hippodrome Sopot in Sopot and since 2012 also the Cracow Racecourse in Buczkowo-Dąbrówka (near Bochnia) ${ }^{12}$. Although, comparing to other European countries, there are not too many facilities, these are the objects of the
highest quality, and modernizations currently being carried out on their areas can serve as model examples of such transformations.
4. TWKS - Tor Wyścigów Konnych Służewiec w Warszawie liuszem Ż́́ra wyscigowy zaprojektowa Ple wspólpracy z Juczerwca 1939 roku obiekt byt w swoim czasie najnowocześ3 czerwca 1939 roku obiekt był w swoim czasie najnowoczes który już w trakcie budowy nazywano "miasteczkiem wyścigowym". W obrębie założenia, zajmującego teren 138 ha, zaplanowano dwa tory wyścigowe - główną bieżnię trawiast o długości $2300 \mathrm{~m}$, rozwiniętą $w$ osi połnoc-południe, na które odbywaja się wyscigi plaské oraz piaszczysta bieżnie treninrybun, przeznaczonych dla użytkowników o różnm statusie ypotecznym - jednak jedne z nich nigdy nie ukończono. Plan a beimowat równiez min mieszkania dla pracowników magazyny (w tym silos na 550 ton ziarna), stainie dla ponad 800 kon studnie, parking a nawet wieże ciśnień. Na uwage zasługuje także niebanalne założenie zieleni, na które składa sie przeszło 6000 krzewów różnych rodzajów i 95 gatunków drzew. Obecnie układ funkcjonalno-przestrzenny TWKS wpisany jest ków. Od roku 2008 prowadzony jest program modernizaci toru, polegający na remontach i odnowie zabytkowej infrastruktury, a takze nowych inwestycjach. Rozwoj ossrodka realizowany jest w oparciu o rozwiązania przyjęte na świecie, kcje wyścigow konnych i zada-

5. WTWK - Wrocławski Toru Wyścigów Konnych - Partynice ${ }^{15}$ Wrocławski tor wyścigowy, położony na terenie osiedla Partynice został zaprojektowany przez architekta R. Jürgensa mowało: tor gtówny o długości 2150 metrów, dwie trybuny wieże sedziowska budynek zarzadu i herbaci, dwie trybuny, wana przez wspomnianego juz architekta Otto Marcha), ujezdżanie $z$ urzadzeniami do treningu koni, stajnie, kuzhne dozorcy W swoim czasie wrocławskie założenie dorównywa to podobnym obiektom europejskim, a nowoczesna koncepcja parku jeździeckiego służacego szeroko pojetej rekreacii była całkowicie nowatorska. Jasne ściany szachulcowej architektury kontrastujące z graficznym, ciemnym rysunkiem drewnianych belek, podkreślały zamierzony przez architekta, rustykalno-angielski klimat ziemskiej posiadłości w krajobrazowym parku [Chmielewska 2007]. Obecnie (2018 r.) planowana jest. dalsza rozbudowa toru WTWK Partynice i jego infrastruktury. Przewidywana jest m.in. budowa: hotelu, centrum konferencyjno - biurowego, stajni gościnnej dla koni jeźdźców przyjeżdżających na zawody, centrum edukacji ekologicznej, nowyc krytych hal rekreacji hipoterapii, a takze wielu innych udogodWTWK ma powstać także centrum szkoleń jeźdr. Na terenie WTWK ma powstac także centrum szkolen jeździeckich oraz W bieżacym roku planowana jest budowa parku lineanego wokót toru wyścigowego wraz z przyrodnicza ścieża eduka cyina W wyniku ponomanych zziałá ma powstać ogólnodostepny park o wysokich walorach przyrodniczych, podnoszacy różnorodność biologiczną terenu i stanowiacy uzupetnien funkcji rekreacyjnych i sportowych założenia ${ }^{17}$

6. Hipodrom Sopot ${ }^{18}$

Sopockie założenie o powierzchni około 31 ha składa się $\mathrm{z}$ toru trawiastego do wyścigów płaskich o długości 1850
4. TWKS - Słuzewiec Racetrack in Warsaw The Warsaw racecourse was designed by architect zygmunt Plater-Zyberk in cooperation with Juliusz was in its time the most modern and largest hippodrome in Europe, which was already during costruction called "a horse racing town". Within the area of 138 hectares, there are two race tracks - the main grass course for Flat Races with a length of -training track, located on the east-west axis Three grandstands were planned for users with differen social status - however, one of them was never completed. The plan also includes: flats for employees, warehouses (with silos for 550 tons of grain, stables for over 800 horses, wells, parking and eve project of greenery which consists of over 6000 types of shrubs and 95 species of trees.

Currently, the functional and spatial layout of TWKS is register as Historical Monument. Since ried out, consisting of renovation and renewal of historic infrastructure, as well as new investments. evelopment of the center is bae horse rac作 successfully combined'

5. WTWK - Wroclaw Racecourse in Partynice 15 Partynice, was designed by architect $R$. Jürgen from Hamburg and put into service in 1907. The facility includes: main course with a length of 2150 meters, two stands, a judges tower, administration
building and tea-house (designed by the already
mentioned architect Otto March), riding halls with horse training equipment, stables, a forge and a janitor's house. At the beginning of $20^{\text {th }}$ century Wroclaw hippodrome matched similar European
facilities, and the modern concept of a riding park serving for recreation purposes was even completely innovative. The bright walls of timbered architecture contrasting with its dark wooden beams enhanced the rustic atmosphere of the Currently (2018), further development of the WTWK Racecourse and its infrastructure is planned. It is ence and office center, guest stables for horses of riders coming to the competition, ecological education center, new indoor halls for recreation and hippotherapy, as well as many other facilities such WTWK, center for equestrian training and center for professional horse riding for school children will be created, as well16. This year, the construction of a linear park around the racetrack, alon with the educational path is planned. As a resulf of the design, a publicly accessible park with high diversity of the area and complementing its recreational and sports functions ${ }^{17}$.

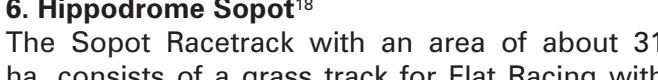
ha, consists of a grass track for Flat Racing with
a length of $1850 \mathrm{~m}$, a working sand track with length of $1600 \mathrm{~m}$ and a green track plack with hurdles for Jump Racing. The stands are located so 
zielonej płyty toru z 24 przeszkodami. Trybuny są ulokowane kreacyjne, centrum hipoterapii, drewniana trybuna z $1885 \mathrm{r}$. (a) sami z 1926 r., budynek dźokejki wraz z pomieszczeniami dla sędziów i waga, padok do prezentacji koni przed wyścigami, takze zabudowania mieszkalne dla uczestników wyścigów. Obecnie hipodrom łaczy funkcję toru wyscigowego, osrodka ponie Na jego terenie znjuje sie rómież penjont dia oni oraz wypożyczalnia powoźm/karet. W grudniu 2013 roku zakończyła sie in

cinewitaNopocie wraz jednym z najnowocześniejszych ośrodków jeździeckich w Europie [il.2].

\section{Podsumowanie}

Tereny współczesnych hipodromów stają się popularnymi miejscami spędzania czasu wolnego, nabierając znaczenia nie tylko w skali miast, ale rownież całych regionów. Współczesne ich planowanie jako tzw. "parkow jeżdzieckich", pozwala sukcesem tączyc podstawową funkcję wyscigową z zadaniami sportowymi i rekreacyjnymi. Dzięki temu hipodromy tają się wielofunkeyjnymi, miejskimi przestrzeniami zielonymi, o dużej wartości tak społecznej jak i krajobrazowej. Ze względu na wielkosc, połozenie oraz znaczny udział terenów zelonych, są one również istotnym ogniwem w systemie zeje

ENDNOTES

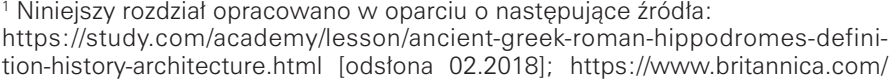

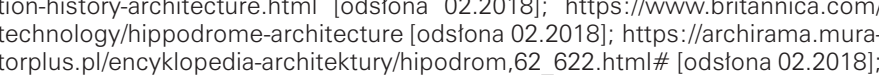

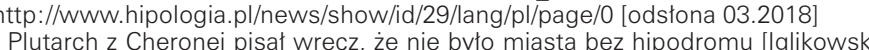
Obecnie na terenie Wiekkiej Brytanii działa 60 hipodromów (https:///www.bri-

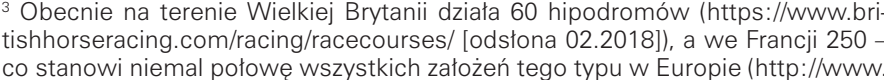

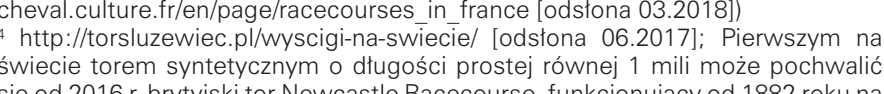
sie od 2016 r. brytyjski tor Newcastle Racecourse, funkcjonujacy od 1882 roku na
przedmiešciach Newcastle upon Tyne na 300 ha terenie Gosforth Park (https:// www.newcastle-racecourse.co.uk/ / Iodstona 02.2018/,
${ }^{5}$ http://www.parislongchamp.com/ / odstona 02.2018

hittp://www.perraultarchitecture.com/en/projects/3015-ongchamp_racecour列 Carr $w$ stylu palladiańskim na brytyjskim torze Yorkville w 1756 roku [Roberts

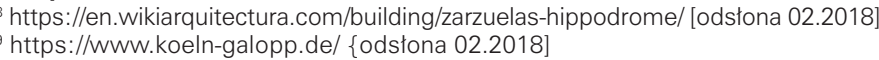
o https://Wwww.ascot.co.uk/ [odstona 06.2017]

odstona 06.2017]

mić po II Wojsinie Swituatowej. Tor ten posiada tml [odsłona 06.2017)] Ze Względu na to, że jest zlokalizowany poza obszarem miejskim nie zostal omowiony szczegolowo w niniejszym artykul

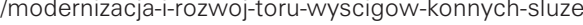

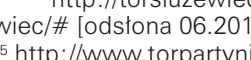

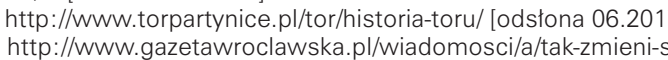

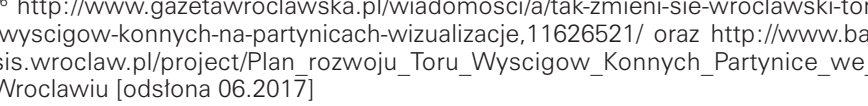

as to additionally provide viewers with a view of the Ballic sela. The complex also iscludes: spons and recreational stables, a EAT center, a wooden grandbuilding with 12 cash registers from 1926, a jockey building with rooms for judges and weight, a paddock for presentation of horses before the races, as well as residential buildings for racing participants. Currently, the hippodrome combices the funcion of as well as a EAT center. There is anal riding facility horses and a carriages rental.

In December 2013 was completed the investmen titled: "Revitalization of the historical Hippodrom Sopot along with its renovation and extension",

\section{Summary}

The areas of contemporary hippodromes become popular places of everyday leisure, gaining significence canestrian parks", allows to successfully combine heir basic racing function with sports and recreational tasks. Thanks to this, hippodromes become multifunctional, urban green spaces with a high sociand landscape value. Due to the size, location and cells in the green infrastruct re system, thus paying a significant role in sustainable urban development. ENDNOTES

1 This chapter is based on the following sou -hippodromes-definition-history-architecture.html [access 02.2018): https://WWw.britannica.com/technology/hippodro-

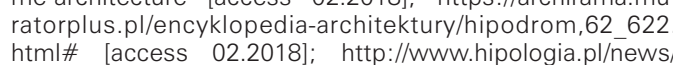
html/t laccess 02.2018]; http://Www.hipologia.pl/news/ show/id/29//ang//////age/// [access 03.2018] a hippodrome [lglikowski 2010].

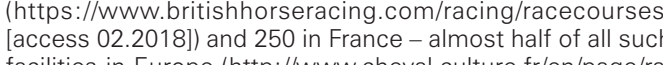
facilities in Europe (http://Www.cheval. culture.fr/en/page/r-
cecourses in france [access 03.2018)] ${ }^{4}$ http://torsluzewiec.pl/wyscigi-na-swieciel/ [access 06.2017 ]
The first synthetic track in the world with a 1 mile long striThe first synthetic track in the world with a 1 mile long stra-
ight line belongs since 2016 to the British Newcastle Ra-

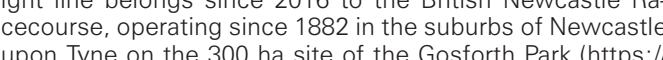

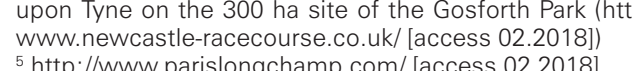

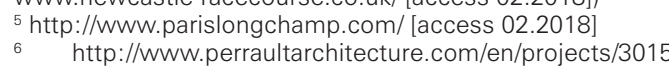
-longchamp_racecourse.html laccess 02.20

7 The oldest stand for viewers was designed by architec ${ }_{8}^{\text {cecourse in } 1756 \text { [Roberts } 20}$ https://en. wikiarquitect

podrome// [access 02.2018$]$
जhtps:

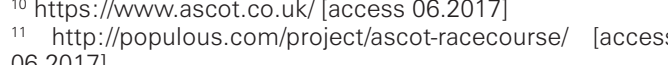
06.20177
12 12 KTWK is the first private racetrack in the Matopolska vo
vodship, which was managed to run after the Second World War (http://Www.ktwk.pl/p//strony/o torze.html [access
$06.2017]$ ) Due to the fact that it is located outside the urban area, it has not been discussed in detail in this article.
${ }_{13} \mathrm{http}: / /$ torsluzewiec.pl/historia-toru/ [access 06.2017 ]

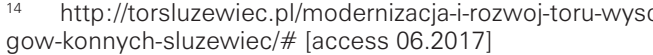

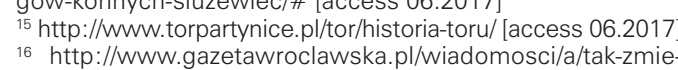

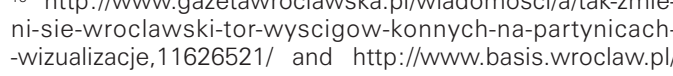

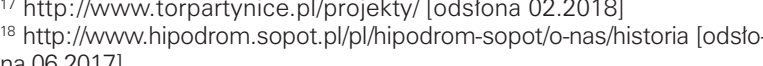

LITERATURA

1] Chmielewska M., Eysymontt D., Eysymontt R., 100 lat Toru Wyśc
gów Konnych Wroctaw - Partynice 1907-2007. Wydawnictwo i Dru karnia Semata Sp. z o. O. Wroclaw 2007, http://www.torpartynice.p/

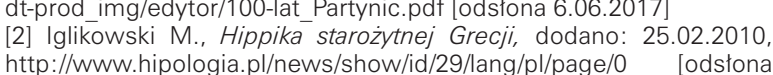
http://Www.hipologia.p//news/show/id/29/lang/p//page/0 lodstona 03.2018]
[3] John G., Sheard R., Vickery B., Stadia: The Populous Design and
Development Guide, Routledge 2013, ISBN 978-0-415-52270-0 4] Roberts P. Taylor I. R [5] Tarajko-Kowalska J., Metges H., Cygankiewicz I., Miejskie farmy ze
zwierzętami, ogrody edukacyine i ośrodki jeżdzieckie - idea, funkcje, 2wianowanie / City farms with animals, educational gardens and equ planowanie / City farms with animals, educational gardens and equ-
estrian centres- idea, functions and planning aspects Wydawnictwo
Politechniki Krakowskiej, Kraków 2017. ISBN 978-83-7242-969-8str. Politechniki Krakowskiej, Krakow 2017, ISBN 978-83-7242-969-8st.
$52-56$

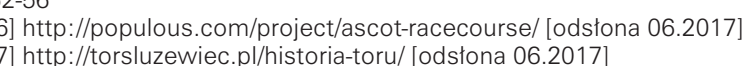

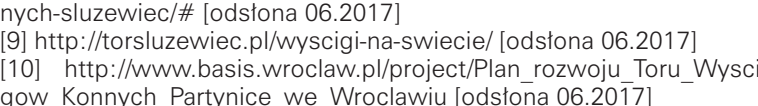
(11] http://www. cheval.culture. .rflen/page/racecourses in france lod

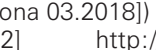

-sie-wroclawski-tor-wyscigow-konnych-na-partynicach-wizualizacje, 11626521/ [odstona 06.2017]

W01.hipodrom sopot p/p//hipodrom-sopot//-nas/historia

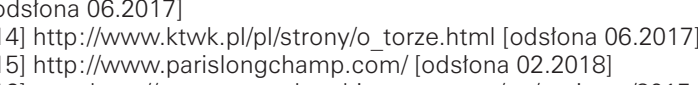

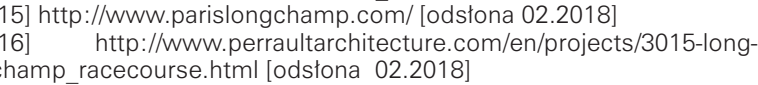

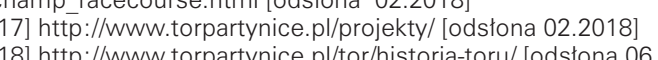

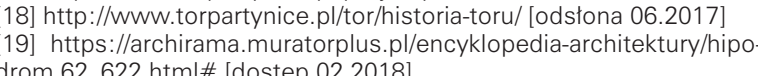

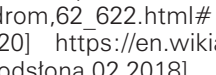

21] https://study.com/academy/lesson/ancient-greek-roman-hip-

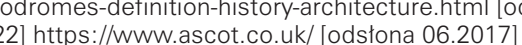

[23] https://Mww.britannica.com/technology/hippodrome-architectu re [odstona 02.2018]
[24] https://www.british na 02.2018$]$

27] https://Www.newcastle-racecourse.co.uk/ [odstona 02.2018]

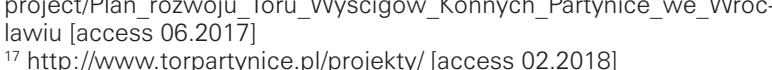

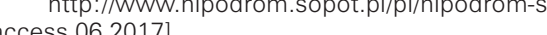

BBLIOGRAPHY

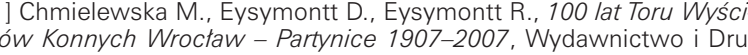
D.
W dt-prod img/edytor/100-lat_Partynic.pdf [access 6.06.2017]
2] Iglikowski M., Hippika staroziytnej Grecji, dodano: 25.02.2010 03.2018] [access 3) John G., Sheard R., Vickery B., Stadia: The Populous Design and
Development Guide, Routledge 2013, ISBN 978-0-415-52270-0 4) Roberts P., Taylor I., Racecour

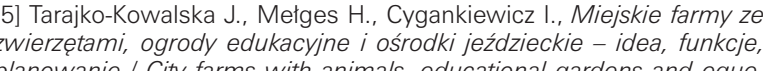
planowanie / I Sity farms with animals, educational gardens and eque

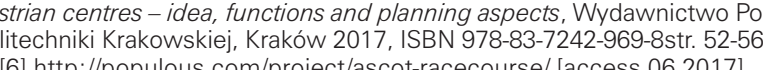

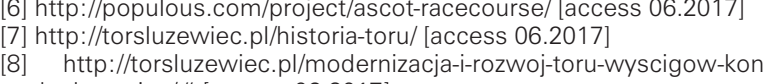
nych-sluzewiec/\# laccess 06.2017]

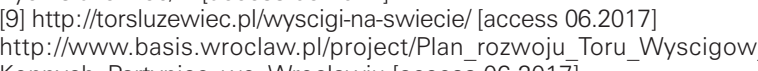

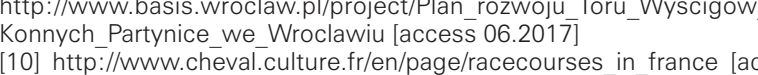

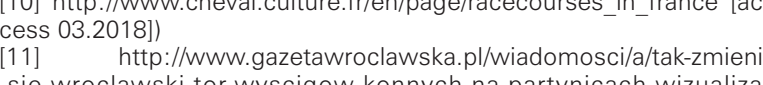

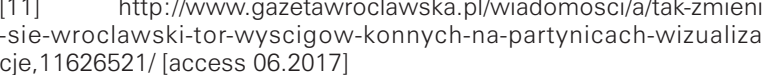
[12] htsp //www hipodrom.sopot.pl/pl/hipodrom-sopot/o-nas/historit 13] http://Www.ktwk.p//////strony/o_torze.html [access 06.2017]

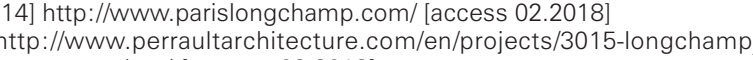
racecourse.html laccess 02.2018$]$
$[15]$ http://www.torpartynice.pl/projekty/ [access 02.2018]

[16] http:///4ww.torpartynice.pl/tor/historia-toru/ [access 06.2017]
(17] https:///2rchirama.muratorplus.pl/encyklopedia-architektury/hipodrom, 62 622.html\# [dostep 02.2018]
[18] https://en.wikiarquitectura.com/building/zarzuelas-hippodrome/

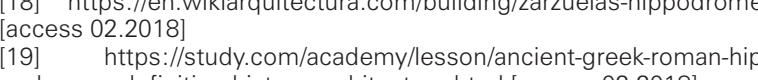

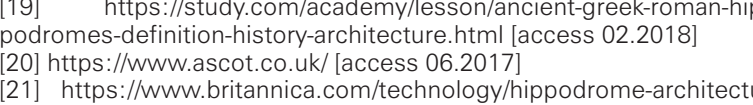
[21] https://Www.britannica.com/technology/hippodrome-architectu-
re laccess 02.2018$]$

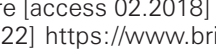

$02.2018]$

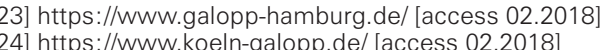

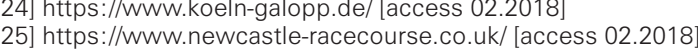

